\title{
PERAN KEPEMIMPINAN KEPALA SEKOLAH DALAM MENINGKATKAN KEDISIPLINAN SISWA DI SDN EMBUNG TANGAR KECAMATAN PRAYA BARAT
}

\author{
Febria Kurniasih ${ }^{1}$, Hadi Wijaya ${ }^{2}$ \\ Pendidikan Guru Sekolah Dasar, Universitas Nahdlatul Ulama NTB \\ febriakurniasih1@gmail.com, hadiwijaya.ntb@gmail.com
}

\begin{abstract}
Abstrak. Masalah kedisiplinan siswa menjadi sangat berarti bagi kemajuan sekolah. Hal ini diperlukan kerja keras dari berbagai pihak untuk meningkatkan kedisiplinan, terutama Kepala Sekolah yang sangat berperan sekali dalam mendisiplinkan siswa. Kedisiplinan siswa dalam belajar perlu diupayakan oleh Kepala Sekolah selaku pimpinan pendidikan di lingkungannya dan dibantu oleh guru selaku tenaga pengajar dan pendidik. Tujuan penelitian ini adalah untuk mengetahui peran kepemimpinan Kepala Sekolah di SDN Embung Tangar Praya Barat dan untuk mengetahui peningkatan kedisiplinan siswa di SDN Embung Tangar Praya Barat. Adapun metode penelitian ini menggunakan pendekatan kualitatif deskriptif, yaitu imformasi berupa huruf bukan angka. Adapun imforman dalam penelitian ini adalah Kepala Sekolah, Tenaga Pendidik, Tenaga Kependidikan, siswa, orang tua, dan Komite Sekolah. Teknik pengumpulan data adalah menggunakan teknik observasi, wawancara, dan dokumentasi. Keabsahan data menggunakan tringulasi teknik. Hasil penelitian menunjukkan bahwa, (1) Kepala Sekolah sudah melaksanakan beberapa kompetensi-kompetensi yang sudah dimiliki oleh Kepala Sekolah SDN Embung Tangar adalah: Kompetensi kepribadian, Kompetensi manajerial, Kompetensi kewirausahaan, Kompetensi supervisi, dan Kompetensi sosial. (2) bentuk-bentuk disiplin di SDN Embung Tangar Praya Barat yaitu aspek disiplin dalam mentaati peraturan, disiplin waktu, disiplin belajar, dan disiplin mengerjakan tugas. (3) Faktor pendukung dalam meningkatkan kedisiplinan siswa adalah keikutsertaan komite sekolah dalam mengawasi kegiatan di sekolah, alat proses pembelajaran atau alat-alat peraga, peran guru yang aktif, program makanan tambahan selama 6 bulan yang diberikan oleh pemerintah pusat, adanya aturan-aturan dan tata tertib di sekolah. (4) Faktor penghambat kedisiplinan siswa adalah beberapa siswa sering mengantuk di kelas karena lemas kelaparan disebabkan ada yang tinggal di neneknya dan ada yang ditinggal pergi merantau oleh orang tuanya.
\end{abstract}

Kata kunci: Kepemimpinan, Kepala Sekolah, Disiplin

\section{PENDAHULUAN}

\section{A. Latar Belakang}

Pendidikan merupakan usaha manusia untuk menumbuhkan dan mengembangkan potensi-potensi pembawaan baik jasmani maupun rohani dengan nilai-nilai yang ada dalam masyarakat dan kebudayaan. Usahausaha yang dilakukan untuk menanamkan nilai-nilai dan norma-norma tersebut, serta mewariskan kepada generasi berikutnya untuk dikembangkan dalam hidup dan kehidupan yang terjadi dalam suatu proses pendidikan. Karena itu, bagaimanapun peradaban suatu masyarakat, di dalamnya berlangsung dan terjadi suatu proses pendidikan sebagai usaha manusia untuk melestarikan hidupnya.

Pendidikan harus direncanakan dengan matang mulai dari kepala sekolah, guru, metode belajar, bahkan mengenai budaya kedisiplinan di lingkungan sekolah, agar terwujud suasana pembelajaran yang aktif dan efektif.

Sekolah sebagai institusi pendidikan yang diharapkan mampu meningkatkan kualitas, mutu yang dikelola, diatur, ditata dan diberdayakan, agar dapat menghasilkan produk atau hasil secara optimal. Secara internal, Sekolah memiliki perangkat guru, murid, kurikulum, sarana dan prasarana. 
Sedangkan secara eksternal, sekolah memiliki dan berhubungan dengan instansi lain baik secara vertikal maupun horizontal.

Untuk tercapainya tujuan pendidikan sebagaimana diuraikan di atas, maka diperlukan kerjasama yang baik antara setiap personil yang terdapat disekolah, seperti Kepala Sekolah, Guru, dan siswa, dan saling sinergi antara lingkungan Sekolah dan lingkungan masyarakat. Sekolah sebagai salah satu lingkungan pendidikan harus senantiasa memperhatikan kedisiplinan anak dalam setiap kegiatan yang di selenggarakan khususnya dalam setiap proses pembelajaran. Untuk itu, diperlukan kerjasama antara kepala Sekolah, guru, dan orang tua siswa dalam rangka menumbuhkan atau membina kedisiplinan pada siswa.

Kepala sekolah merupakan salah satu komponen pendidikan yang paling berperan penting dalam meningkatkan kualitas pendidikan. Kepala sekolah adalah seorang tenaga fungsional guru, yang diberi tugas untuk memimpin suatu sekolah dimana diselenggarakannya proses belajar mengajar, atau tempat dimana terjadi interaksi guru dalam memberi pelajaran dan murid menerima pelajaran. Dalam hal ini Kepala sekolah juga penting untuk memberikan perhatian kepada hal-hal yang dapat menggangu upaya-upaya peningkatan kualitas sekolah, diantaranya adalah masalah kedisiplinan.

Masalah kedisiplinan siswa menjadi sangat berarti bagi kemajuan sekolah. Di Sekolah yang tertib akan selalu menciptakan proses pembelajaran yang baik. Sebaliknya, di Sekolah yang tidak tertib kondisinya akan jauh berbeda dari Sekolah yang disiplin. Pelanggaran-pelanggaran yang terjadi sudah dianggap biasa dan untuk meperbaiki keadaan demikian tidaklah mudah. Hal ini diperlukan kerja keras dari berbagai pihak untuk merubahnya, terutama kepala sekolah yang sangat berperan sekali dalam mendisiplinkan siswa.
Berdasarkan hasil observasi awal di SDN 1 Embung Tangar Kecamatan Praya Tengah masalah disiplin pada para siswa terjadi karena adanya beberapa faktor. Seperti masih terdapatnya siswa yang belum mentaati aturan, tidak mendengarkan himbauan guru, faktor keluarga, faktor lingkungan atau faktor pergaulan.

Sehubungan dengan masalah di atas, penulis tertarik dan berkeinginan untuk mengetahui lebih lanjut dengan melakukan penelitian yang berjudul "Peran Kepemimpinan Kepala Sekolah Dalam Meningkatkan Kedisiplinan Siswa Di SDN Embung Tangar Kecematan Praya Barat".

\section{B. Rumusan Masalah}

Berdasarkan latar belakang pemikiran tersebut, maka rumusan masalah adalah sebagai berikut:

1. Bagaimana peran kepemimpinan Kepala Sekolah di SDN Embung Tangar Kecematan Praya Barat?

2. Bagaimana peningkatan kedisiplinan siswa di SDN Embung Tangar Kecematan Praya Barat?

\section{Tujuan Penelitian}

Berdasarkan rumusan masalah di atas maka tujuan yang ingin dicapai dalam penelitian ini adalah:

1. Untuk mengetahui peran kepemimpinan Kepala Sekolah di SDN Embung Tangar Kecematan Praya Barat

2. Untuk mengetahui peningkatan kedisiplinan siswa di SDN Embung Tangar Kecematan Praya Barat

\section{A. Kajian Teori}

\section{Pengertian Peran}

Peran menurut Soerjono Soekanto dalam Imanuel (2015: 1185) merupakan aspek dinamis kedudukan (status). Apabila seseorang melaksanakan hak dan kewajibannya sesuai dengan kedudukannya, maka ia menjalankan suatu peran. Peran setidaknya mencakup 3 hal:

a. Peran meliputi norma-norma yang dihubungkan dengan posisi atau tempat seseorang dalam masyarakat. 
b. Peran adalah suatu konsep mengenai apa yang dapat dilakukan oleh individu dalam masyarakat.

c. Peran dapat dikatakan sebagai perilaku individu yang penting bagi struktur sosial masyarakat.

Selanjutnya Bruce J Cohen dalam Mutiawanthi (2017: 170) mengungkapkan peran terdiri atas harapan-harapan yang melekat pada ciri-ciri perilaku tertentu yang seharusnya dilaksanakan oleh sesorang yang menduduki posisi atau status sosial tertentu dalam masyarakat. Setiap peran memiliki tugas-tugas tertentu yang harus dilaksanakan oleh pengemban peran.

Berdasarkan paparan di atas dapat disimpulkan bahwa peran adalah prilaku individu yang meliputi norma-norma yang dihubungkan dengan posisi atau tempat seseorang di masyarakat dalam menjalankan hak-hak dan kewajiban-kewajibannya.

2. Peran Kepemimpinan Kepala Sekolah a. Pengertian Kepemimpinan

Kepemimpinan berasal dari bahasa Inggris yaitu leader yang berarti pemimpin, selanjutnya leadership berarti kepemimpinan. Pemimpin adalah orang yang menempati posisi sebagai pimpinan sedangkan kepemimpinan adalah kegiatan atau tugasnya sebagai pemimpin (Djafri, 2017: 1).

Sedangkan istilah kepemimpinan, dalam Bahasa Inggris Leadership yang dapat diartikan sebagai hubungan yang erat antara seseorang dan kelompok manusia, karena ada kepentingan sama. Hubungan yang dimaksud adalah tingkah laku yang tertuju dan terbimbing dari pemimpin dan yang dipimpin (Farikhah, 2015: 163).

Kepemimpinan merupakan proses mempengaruhi orang lain untuk mengambil langkah-langkah atau tindakan menuju suatu sasaran bersama. Karena itu kepemimpinan adalah kegiatan mempengaruhi orang lain agar mau bekerja untuk mencapai tujuan yang telah ditentukan (Purwati, 2013: 212).

Berdasarkan pengertian-pengertian di atas, maka dapat disimpulkan bahwa kepemimpinan adalah rangkaian kemampuan dan kepribadian seseorang untuk dapat meyakinkan sekelompok orang, agar mereka mau mengikuti dan bekerjasama dalam rangka mencapai tujuan organisasi Hubungan yang dimaksud adalah tingkah laku yang tertuju dan terbimbing dari pemimpin dan yang dipimpin.

\section{b. Peran Kepala Sekolah}

Kepala sekolah adalah seorang tenaga fungsional guru yang diberi tugas untuk memimpin suatu sekolah dimana diselenggarakan proses belajar mengajar, atau tempat dimana terjadi interaksi antara guru yang memberi pelajaran dan murid yang menerima pelajaran (Karweti, 2010: 80).

Dalam Permendiknas terdapat lima kompetensi Kepala Sekolah yaitu: 1) Kepribadian, 2) Manajerial, Kewirausahaan , 4) Supervisi, 5) Sosial

\section{Kedisiplinan Peserta Didik}

\section{a. Pengertian Disiplin}

Kata disiplin berasal dari bahasa latin discipulus, yang berarti siswa. Namun dalam perkembangannya, kata disiplin ini mengalami perubahan bentuk dan perluasan arti seperti kata diciplina, yang berarti pengajaran atau pelatihan (Susanto, 2018: 117).

Menurut Hurlock dalam (Susanto, 2018: 117) mengemukakan bahwa "discipline is training in self control of education (teaching children what of perfect children to follow the rules". Jadi menurut Hurlock disiplin adalah cara untuk melatih individu atau seseorang dalam kontrol diri atau melatih individu mengerti apa yang boleh dan tidak boleh mereka perbuat sesuai dengan peraturan yang berlaku di masyarakat. 
Lebih lanjut Lindgren dalam (Susanto, 2018: 118) mengemukakan bahwa ada tiga pengertian pokok mengenai pengertian disiplin, yaitu: 1) Punishment, 2) Control by enforcing obedence of orderly conduct, 3) Training that correct and strengthens (disiplin diri).

Dari uraian mengenai pengertian disiplin yang telah dikemukakan oleh para ahli di atas, maka dapat disimpulkan pengertian disiplin, terutama yang berkaitan dengan belajar, disiplin adalah suatu sikap yang menunjukkan keterkaitan siswa terhadap peraturan sekolah. Disiplin adalah suatu keadaan tertib dimana orang-orang yang tergabung dalam suatu sistem tunduk pada peraturan-peraturan dengan senang hati.

\section{b. Pentingnya Disiplin}

Sekolah yang disiplin akan melahirkan kondisi yang baik, nyaman , tentram dan teratur. Istilah disiplin berasal dari kata yang sama dengan "disciple yang artinya seorang yang belajar dari atau secara sukarela mengikuti seorang pemimpin (Aulia, 2013: 37).

Kedisiplinan akan menciptakan kesediaan atau ketaatan seluruh warga sekolah untuk mematuhi aturan, tata tertib, norma yang telah dibuat oleh pemimpin dan guru yang dilandasi oleh kesadaran dan kesediaan dalam diri setiap siswa.

\section{c. Pembinaan Disiplin Peserta Didik}

Kedisiplinan peserta didik di sekolah mencakup perilaku yang harus dilakukan peserta didik, berupa kewajiban dan perilaku yang harus dihindari. Kedua kelompok perilaku dirumuskan secara tertulis ke dalam bentuk peraturan dan tata tertib sekolah. Namun demikian, peraturan dan tata tertib yang tidak tertulis juga senantiasa ada di sekolah ataupun di masyarakat.

Adapun unsur-unsur disiplin yang dikemukakan oleh Hurlock dalam (Susanto, 2018: 124) adalah sebagai berikut:
1) Peraturan

Peraturan adalah pola yang ditetapkan untuk berbuat atau bertingkah laku. Tujuannya adalah membekali anak dengan pedoman perilaku yang disetujui dalam situasi dan kelompok tertentu.

2) Hukuman

Hukuman berasal dari kata latin Pinier yang berarti menjatuhkan hukuman kepada seseorang karena kesalahan, perlawanan atau pelanggaran sebagai ganjaran atau pembalasan. Hukuman memiliki tiga fungsi, yaitu: 1) menghalangi pelanggaran tindakan, 2) mendidik, 3) memberi motivasi.

3) Konsistensi

Konsistensi berarti tingkat keragaman atau stabilitas, mempunyai tiga fungsi, yaitu: 1) mempunyai nilai mendidik yang besar, 2) mempunyai nilai motivasi yang kuat untuk melakukan tindakan yang baik di masyarakat, 3) membantu perkembangan anak untuk hormat pada aturan dan masyarakat sebagai otoritas.

Berdasarkan beberapa faktor yang telah dijelaskan, hal terpenting dalam pembentukan disiplin siswa, yaitu siswa harus mampu melaksanakan disiplin atas kesadaran sendiri, jika mereka memiliki pemikiran positif terhadap disiplin bahwa disiplin bukanlah sesuatu yang harus dipaksakan, tetapi datang dari kesadaran diri sendiri, maka hal itu akan membuat siswa memiliki keyakinan terhadap disiplin.

\section{METODE PENELITIAN}

Jenis penelitian ini adalah penelitian kualitatif. Menurut Sugiyono (2013:9) metode penelitian kualitatif adalah metode yang berlandaskan pada filsafat postpositivisme, digunakan untuk meneliti pada kondisi objek alamiah, (sebagai lawannya adalah eksperimen) dimana peneliti adalah sebagai instrument kunci, teknik pengumpulan data dilakukan secara gabungan, analisis data bersifat induktif/kualitatif, dan hasil penelitian kualitatif 
lebih menekankan makna daripada generalisasinya.

\section{PEMBAHASAN}

\section{A. Hasil Penelitian}

\section{Peran Kepemimpinan Kepala Sekolah di} SDN Embung Tangar

Kepala Sekolah SDN Embung Tangar sudah melaksanakan kompetensikompetensinya sebagai Kepala Sekolah yaitu:

a. Kepribadian

Kepribadian Kepala Sekolah memiliki integritas kepribadian sebagai pemimpin senantiasa harus bisa mengembangkan sekolah supaya siswasiswanya nyaman belajar sehingga ada peningkatan terhadap siswa dan guru.

b. Manajerial

Kepala Sekolah sudah melaksanakan perannya sebagai manajer yaitu dengan membuat program-program. Pertama jam 07:30 semua siswa harus sudah berada di dalam kelas, kedua Kepala Sekolah selalu mengawasi dan mengontrol kedisiplinan siswa maupun guru-guru di sekolah SDN Embung Tangar dengan melakukan kerjasama antara siswa, guru, dan Kepala Sekolah.

c. Kewirausahaan

Permasalahan utama yang dihadapi dalam penanaman kedisiplinan oleh Kepala Sekolah adalah karena karakter siswa yang berbeda-beda dikarenakan siswa yang sangat banyak. Akan tetapi Kepala Sekolah dan para guru akan tetap memperlurus dan memperbaiki karakterkarakter siswa yang menyimpang dari aturan melalui kegiatan-kegiatan Pramuka. Karena di dalam Pramuka, siswa-siswa tersebut dilatih untuk disiplin, seperti selalu bekerjasama dengan teman-temannya, belajar tepat waktu, bangun tepat waktu, sholat tepat waktu dan lain sebagainya.

d. Supervisi

Salah satu bentuk pengawasan yang dilakukan oleh kepala sekolah SDN
Embung Tangar adalah dengan melakukan kunjungan kelas. Kunjungan kelas yang sewaktu-waktu dilakukan oleh kepala sekolah untuk evaluasi terhadap guru dan siswa.

e. Sosial

Kepala Sekolah sudah bekerjasama dan melaksanakan program dengan pihak lain yaitu program pemberian makanan tambahan selama 6 bulan dari pemerintah pusat yang diresmikan oleh Pak Yusuf Kala, sehingga kedisiplinan siswa menjadi meningkat, yaitu peningkatan masuk kelas tepat waktu dan pulangnya pun tepat waktu.

\section{Peningkatan kedisiplinan siswa di SDN} Embung Tangar Kecamatan Praya Barat

a. Faktor Pendukung dan penghambat dalam meningkatkan kedisiplinan siswa

Faktor pendukungnya adalah sebagai berikut: 1) Keikutsertaan komite sekolah dalam mengawasi kegiatan di sekolah, 2) Alat proses pembelajaran atau alat-alat peraga, 3) Peran guru yang aktif, 4) Program makanan tambahan selama 6 bulan yang diberikan oleh pemerintah pusat

Sedangkan faktor penghambat kedisiplinan siswa yaitu Beberapa siswa sering mengantuk di kelas karena lemas kelaparan disebabkan ada yang tinggal di neneknya dan ada yang ditinggal pergi merantau oleh orang tuanya.

b. Bentuk-bentuk penanaman disiplin di SDN Embung Tangar

1) Disiplin waktu

Dalam menanamkan kedisiplinan pada siswa maka harus ditetapkan aturan datang tepat waktu yaitu jam 07:30 harus sudah berada di dalam kelas. Dan bagi siswa yang sering terlambat maka akan dikenakan sanksi dan dipanggil orang tuanya.

Budaya disiplin yang diterapkan di SDN Embung Tangar sudah menjadi aktifitas yang tercermin dalam diri siswa. Misalnya, siswa sampai 
sampai di sekolah sebelum jam 07:30 atau sebelum jam pelajaran dimulai, mengucap salam dan bersalaman kepada guru sebelum dan sesudah pembelajaran berlangsung dan lainlain. Hal tersebut membuktikan bahwa siswa sudah terbiasa melakukan kegiatan yang mencerminkan sikap disiplin.

2) Disiplin belajar

Kedisiplinan belajar ditanamkan dengan cara sebelum memulai pembelajaran setiap guru kelas maupun guru olahraga mengajak anakanak berdo'a bersama, kemudian membaca perkalian, dan membaca ayat-ayat pendek. Kemudian, ketika proses pembelajaran berlangsung ada anak yang ribut, maka guru memberi pertanyaan kepada anak tersebut supaya anak tersebut diam dan siswa yang lain memperhatikan dan menyimak pertanyaan tersebut.

3) Disiplin mengerjakan tugas

Kedisplinan mengerjakan tugas dilaksanakan dengan cara Jika ada salah satu siswa tidak melaksanakan tugas atau mengerjakan PR. Pertama yang kita lakukan adalah menanyakan, bukan langsung dalam bentuk hukuman. Siswa yang tidak mengerjakan tugas akan diberikan sanksi sesuai dengan perjanjian yang sudah ditetapkan antara guru dan siswa yang tidak mengerjakan tugas.

\section{B. Pembahasan}

\section{Peran Kepemimpinan Kepala sekolah di SDN Embung Tangar Kecamatan Praya Barat}

$$
\begin{aligned}
& \text { Kepala Sekolah SDN Embung } \\
& \text { Tangar sudah melaksanakan beberapa } \\
& \text { kompetensi-kompetensinya sebagai Kepala } \\
& \text { Sekolah. }
\end{aligned}
$$

a. Kepribadian

Salah satu kompetensi kepribadian yang sudah dimiliki oleh Kepala Sekolah SDN Embung Tangar adalah memiliki integritas kepribadian sebagai pemimpin. Kepala Sekolah SDN Embung Tangar sudah mengembangkan sekolah dengan mendapatkan bangunan yang lebih baik sehingga siswa-siswanya nyaman belajar. Jika siswa-siswa tersebut sudah nyaman belajar, maka akan ada peningkatan motivasi dan semangat belajar terhadap siswa-siswa tersebut. Begitu pula dengan guru-gurunya, jika siswa-siswanya semangat belajar, maka gurupun akan semakin mudah untuk mengembangkan kretifitasnya dalam mengajar.

b. Manajerial

Beberapa kompetensi manajerial sudah dimiliki oleh Kepala Sekolah SDN Embung Tangar diantaranya adalah dapat mengelola perubahan dan pengembangan sekolah/madrasah menuju organisasi pembelajar yang efektif dan menciptakan budaya dan iklim sekolah/ madrasah yang kondusif dan inovatif bagi pembelajaran peserta didik melalui kerjasama atau kooperatif. Kepala Sekolah SDN Embung Tangar sudah melaksanakan perannya sebagai manajer yaitu dengan membuat program-program. Pertama jam 07:30 semua siswa harus sudah berada di dalam kelas, kedua Kepala Sekolah selalu mengawasi dan mengontrol kedisiplinan siswa maupun guruguru di sekolah SDN Embung Tangar dengan melakukan kerjasama antara siswa, guru, dan Kepala Sekolah.

c. Kewirausahaan

Salah satu kompetensi yang sudah dimiliki Kepala Sekolah SDN Embung Tangar adalah memiliki motivasi yang tinggi, yaitu pantang menyerah dan selalu mencari solusi terbaik dalam menghadapi kendala yang dihadapi sekolah/madrasah. Permasalahan utama yang dihadapi oleh Kepala Sekolah dalam penanaman kedisiplinan adalah karena karakter siswa yang berbeda-beda dikarenakan siswa yang sangat banyak yaitu berjumlah 249 siswa. Akan tetapi Kepala Sekolah dan para guru akan tetap memperbaiki karakter-karakter 
siswa yang menyimpang dari aturan melalui kegiatan-kegiatan Pramuka. Karena di dalam Pramuka, siswa-siswa tersebut dilatih untuk disiplin, seperti selalu bekerjasama dengan teman-temannya, belajar tepat waktu, bangun tepat waktu, sholat tepat waktu dan lain sebagainya.

d. Supervisi

Beberapa kompetensi yang sudah dimiliki oleh Kepala Sekolah SDN Embung Tangar adalah melaksanakan supervisi akademik terhadap guru dengan menggunakan pendekatan dan teknik supervisi yang tepat dan menindaklanjuti hasil supervisi akademik terhadap guru dalam rangka peningkatan profesionalisme guru. Supervisi yang dilakukan oleh Kepala Sekolah adalah mengevaluasi guru dan siswa, yaitu Kepala Sekolah mengevaluasi mengenai nilai siswa dan rekapitulasi kenaikan kelas.

e. Sosial

Salah satu kompetensi sosial yang sudah dimiliki oleh Kepala Sekolah SDN Embung Tangar adalah bekerjasama dengan pihak lain untuk kepentingan sekolah/madrasah. Kepala Sekolah sudah bekerjasama dan melaksanakan program dengan pihak lain yaitu program pemberian makanan tambahan selama 6 bulan dari pemerintah pusat yang diresmikan oleh Pak Yusuf Kala, sehingga kedisiplinan siswa menjadi meningkat, yaitu peningkatan masuk kelas tepat waktu dan pulangnya pun tepat waktu.

2. Peningkatan Kedisiplinan Siswa di SDN Embung Tangar Kecamatan Praya Barat

Sikap disiplin akan terwujud jika di tanamkan disiplin secara serentak di semua lingkungan kehidupan masyarakat, termasuk dakam lingkungan sekolah. Penanaman disiplin pelajar indonesia harus berlanjut dengan pemeliharaan disiplin dan pembinaan terus menerus, karena disiplin sebagai sikap mental dapat berubah dan dapat dipengaruhi oleh lingkungan sekitar.
Faktor pendukung dalam meningkatkan kedisiplinan siswa adalah sebagai berikut:

a. Keikutsertaan komite sekolah dalam mengawasi kegiatan di sekolah

b. Alat proses pembelajaran atau alat-alat peraga

c. Peran guru yang aktif

d. Program makanan tambahan selama 6 bulan yang diberikan oleh pemerintah pusat

e. Adanya aturan-aturan dan tata tertib di sekolah

Faktor penghambat kedisiplinan siswa adalah beberapa siswa sering mengantuk di kelas karena lemas kelaparan disebabkan ada yang tinggal di neneknya dan ada yang ditinggal pergi merantau oleh orang tuanya.

a. Bentuk-bentuk disiplin di sekolah

Untuk merealisasikan kedisiplinan sekolah, maka kedisiplinan sekolah dapat berupa: 1) Disiplin waktu, 2) Disiplin belajar, 3) Disiplin mengerjakan tugas.

b. Faktor yang mempengaruhi kedisiplinan belajar siswa di sekolah antara lain:

1) Hukuman

Kepala Sekolah dan guru-guru di SDN Embung Tangarmenerapkan aturan bahwa bagi siswa yang melanggar peraturan di sekolah khususnya di dalam kelas maka siswa tersebut dihukum dengan dimasukkan ke dalam ruang BP untuk membaca. Dan bagi siswa yang tidak mengerjakan PR, maka siswa tersebut dihukum untuk mengerjakan soal yang lebih banyak.

2) Penghargaan

Pemberian penghargaan terhadap siswa adalah salah satu trik seorang guru untuk membuat siswanya semakin semangat belajar dan bisa meningkatkan kedisiplinan anak. Seperti yang diterapkan oleh Kepala Sekolah dan para guru di SDN Embung Tangar bahwa untuk membuat siswa lebih semangat belajar dan semakin termotivasi, maka para guru memberikan penghargaan kepada siswasiswa tersebut berupa buku. 


\section{KESIMPULAN DAN SARAN}

\section{A. Kesimpulan}

Kepala Sekolah sudah melaksanakan beberapa kompetensi-kompetensi yang sudah dimiliki oleh Kepala Sekolah SDN Embung Tangar adalah: Kompetensi kepribadian, Kompetensi manajerial, Kompetensi kewirausahaan, Kompetensi supervisi, dan Kompetensi sosial.

Disiplin siswa di SDN Embung Tangar Kecamatan Praya Barat sudah menjadi pembiasaan individu pada diri siswa. Bentuk-bentuk disiplin siswa yang telah diterapkan dan dibiasakan di SDN Embung Tangar Kecamatan Praya Barat adalah meliputi aspek disiplin waktu, disiplin belajar, dan disiplin mengerjakan tugas.

Faktor pendukung peningkatan disiplin siswa di SDN Embung Tangar Kecamatan Praya Barat adalah Keikutsertaan komite sekolah dalam mengawasi kegiatan di sekolah, alat proses pembelajaran atau alat-alat peraga, peran guru yang aktif, program makanan tambahan selama 6 bulan yang diberikan oleh pemerintah pusat, adanya aturan-aturan dan tata tertib di sekolah. Faktor penghambat kedisiplinan siswa adalah beberapa siswa sering mengantuk di kelas karena lemas kelaparan disebabkan ada yang tinggal di neneknya dan ada yang ditinggal pergi merantau oleh orang tuanya dan karakter siswa yang berbeda-beda.

\section{B. Saran}

Berdasarkan temuan-temuan dan kesimpulan hasil penelitian, maka terdapat beberapa saran yang perlu disampaikan guna perbaikan di masa yang akan datang, yaitu:

1. Bagi Kepala Sekolah

a. Membuat kalender akademik khusus untuk sekolah yang berisi tentang perencanaan kegiatan supervisi yang akan dilakukan.

b. Melaksanakan supervisi individul seperti observasi atau kunjungan kelas untuk mengetahui kekurangan guru dalam menerapkan peraturan dan memberikan berbagai penguatan untuk guru dalam menjalankan kedisiplinan.

2. Bagi Guru

a. Guru agar meningkatkan tingkat kedisiplinan dengan datang ke sekolah tepat waktu.

b. Melakukan tindakan atas pelanggran yang dilakukan para siswa dengan memperhatikan faktor psikologis siswa.

\section{DAFTAR PUSTAKA}

Anwar, Muhammad. 2014. Filsafat Pendidikan. PT Kharisma Putra Utama. Jakarta

Agustina, Nora. 2018. Perkembangan Peserta Didik. Grup Penerbit CV Budi Utama. Yogyakarta

Agustin, Aulia. 2013. Pengaruh Pengalaman, Independensi, Dan Due Profesional Care Auditor Terhadap Kualitas Audit Laporan Keuangan Pemerintah (Studi Empiris pada BPK-RI Perwakilan Provinsi Riau). http://ejournal.unp.ac.id. Diakses 20 April 2015

Choirun Nisak Aulia. "Peneneman Disiplin Pada Anak Usia Dini”. Jurnal Pedagogia. Vol 3, no 3, November, 2013

Deddy, Mulyana. 2010. Metode Penelitian Kualitatif. PT Remaja Rosdakarya. Bandung

Dafit Nur Hidayanto. "Perancangan Sistem Informasi Tata Tertib Siswa Pada SMP Negeri 1 Jepara Dengan Menggunakan Sms Gateway". Seminar Riset Unggulan Nasional Informatika dan Komputer FTI UNSA, Vol 2, no 3, November, 2013

Dewi Puspitaningrum. "Implementasi Tata Tertib Sekolah Dalam Membentuk Disiplin Siswa Di Smp Negeri 28 Surabaya". Kajian Moral Dan Kewarganegaraan. Vol 2, no 5, April, 2014

Djafri, Novianty. 2017. Manajemen Kepemimpinan Kepala Sekolah, Pengetahuan Manajemen, Efektivitas, Kemandirian Keunggulan Bersaing dan 
Kecerdasan Emosi. CV Budi Utama. Jakarta

Farikhah, Siti. 2015. Manajemen Lembaga Pendidikan. Aswaja Pressindo. Yogyakarta

Gunawan, Imam. 2014. Metode Penelitian Kualitatif, Teori dan Praktik. Bumi Aksara. Jakarta

Hakim, Lukman. 2008. Manajemen Pendidikan. Genta Press. Yogyakarta

Indah Pratiwi. "Penerapan Konseling Kelompok Behavior Untuk Meningkatkan Kedisiplinan Siswa Di Sekolah Sman 1 Kedungadem Bojonegoro". Jurnal BK UNESA,. Vol 3, no 5, Oktober, 2013

Jelantik, Ketut. 2015. Menjadi Kepala Sekolah Yang Profesional. CV Budi Utama. Yogyakarta

Karweti, Engkay. "Pengaruh Kemampuan Manajerial Kepala Sekolah Dan Faktor Yang Mempengaruhi Motivasi Kerja Terhadap Kinerja Guru SLB Di Kabupaten Subang". Jurnal Pendidikan. Vol 11, no 5, Januari, 2015

Kompri. 2017. Standardisasi Kompetensi Kepala Sekolah "Pendekatan Teori untuk Praktik Profesional. Kencana. Jakarta

Susanto, Ahmad. 2018. Bimbingan dan Konseling di Sekolah, Konsep, Teori, dan Aplikasinya. Prenada Media Group. Jakarta 